Journal of Biotechnology and Strategic Health Research

\author{
Research Article / Araştırma Makalesi
}

http://dergipark.org.tr/tr/pub/bshr

\title{
Aile Hekimlerinin Maternal Kronik Hepatit B Enfeksiyonu Yönetimi Hakkındaki Farkındalık Durumu
}

\author{
Awareness of the Management of Maternal Chronic Hepatitis B Infection among \\ Family Physicians
}

(1) $\square$ Handan Alay

Atatürk Üniversitesi Tıp Fakültesi, Enfeksiyon Hastalıkları ve Klinik Mikrobiyoloji Anabilim Dalı, Erzurum

ORCID ID: Handan Alay 0000-0002-4406-014X

^Sorumlu Yazar / Corresponding Author: Dr. Handan Alay, e-posta / e-mail: alayhandan@gmail.com

Geliş Tarihi / Received: 09-07-2020 Kabul Tarihi / Accepted: 04-12-2020 Yayın Tarihi / Online Published: 31-12-2020

Atıf Gösterimi/How to Cite: Alay H. Aile Hekimlerinin Maternal Kronik Hepatit B Enfeksiyonu Yönetimi Hakkındaki Farkındalık Durumu, J Biotechnol and Strategic Health Res. 2020;4(3):250-256

\footnotetext{
Özet

Amaç Hepatit B virüs (HBV) enfeksiyonu tüm dünyada giderek azalma eğiliminde olan halk sağlığı açısından önemli bir hastalıktır. HBsAg pozitif saptanan gebede hastalığın șiddeti ve tedavi gerekip gerekmediği yakın takip edilmelidir. Bu çalıșmada gebelik ve bebek takiplerinin yakından izleminin yapıldığı birinci basamakta görevli aile hekimlerinin maternal kronik hepatit B yönetimi hakkındaki farkındalıklarını belirlemeyi amaçladık.

Materyal ve Çalışmaya birinci basamak sağlık hizmetlerinde görev yapmakta olan aile hekimleri dahil edildi. Katılımcllara maternal kronik hepatit B enfeksiyonu yönetimi ile ilgili Metod sorular içeren anket elektronik ortamda dolduruldu.

Bulgular Çalışmamıza 125 (\%57.1)'i kadın ve 94 (\%42.9)'ü erkek olmak üzere toplam 219 hekim katıldı. Hekimlerin 43 (\%19.6)'ü aile hekimi uzmanı, 97 (\%44.3)'si aile hekimliği asistanı ve 79 (\%36.1)'i pratisyen hekim olarak çalıșmaktaydı. Katılımcıların yaș ortalaması $31 \pm 7.36$ yll, çalıșma yılı ortalaması $5 \pm 7.6$ yll idi. Hekimlere hepatit B enfeksiyonu hakkında yeterli bilgiye sahip olup olmadıklarını sorduk. 137 (\%62.6) hekim yeterli bilgiye sahip olduğunu belirtti. Hekimlerin 126 (\%30.5)'sı hepatit B virüsünün anneden bebeğe intrauterin dönemde geçtiğini, 195 (\%47.2)'i doğum esnasında ve 92 (\%22.3)'si postnatal dönemde geçtiğini ifade etti. Katılımcıların 187 (\%85.4)'sinin bebeğin emzirilmesinde sakınca olmadığını belirtti. 184 (\%84) hekim gebelik döneminde annelere hepatit B enfeksiyonu taraması yapıldığını, 143 $(\% 65,3)$ hekim HBsAg ve AntiHBs negatif olan gebeye gebelik döneminde hepatit B aşısı yaptırdığını belirtti. Katılımcıların 156 (\%36.4)'sı HBsAg pozitif tespit edilen gebeyi enfeksiyon hastalıkları veya gastroenteroloji uzmanına yönlendirdiğini, hepatit B'li anne bebeğine hepatit B asısı ve hepatit B immünglobulin yapılmalıdır diyen hekimlerin sayısı sırasıyla 178 (\%40.6) ve 197 (\%45) idi. Hepatit B'li anneden doğan bebeğin takibinde $163(\% 38.5)$ hekim "HBsAg pozitif saptanan bebeği pediatrik enfeksiyon kliniğine yönlendiririm", 76 (\%18) hekim "hepatit B aşı uygulamasından sonra AntiHBs bakarım", 72 (\%17) hekim "hepatit B aşı uygulamasından sonra HBsAg bakarım” ve 112 kişi "AntiHBs< $10 \mathrm{IU} / \mathrm{ml}$ olan bebeklere bir kür aşı daha uygularım” șeklinde ifade etti.

Sonuç Gebelik ve bebek takiplerinin düzenli olarak yapıldığı birinci basamak sağlık kurumlarında görev yapan aile hekimlerinin maternal hepatit B virüs enfeksiyonu yönetimi konusunda bilgi eksiklikleri söz konusudur. Gebe ve bebeklerin takibi konusunda aile hekimlerine eğitimler verilmeli, takip süreçlerine yardımcı olacak algoritmalar oluşturulmalı ve Sağlık Bakanlığı politikaları içerisine dahil edilmelidir.

Anahtar aile hekimi, hepatit B, gebelik, HBsAg taraması, hepatit B immunglobulin

Abstract

Aim Hepatitis B virus (HBV) infection is an important disease in terms of public health and one exhibiting a global decreasing trend. The severity of the disease and whether or not treatment is required must be closely monitored in pregnant women identified as HBsAg-positive. The purpose of this study was to determine the awareness of maternal chronic hepatitis B management among family physicians working in primary care providing close pregnancy and baby monitoring.

Material and Family physicians working in primary health services were included in the study. Participants completed a survey containing questions concerning the management of maternal chronic Method hepatitis B infection in an electronic environment.

Results Two hundred nineteen physicians were included, 125 (57.1\%) women and 94 (42.9\%) men. Forty-three (19.6\%) participants were specialist family physicians, 97 (44.3\%) were assistant family physicians, and $79(36.1 \%)$ were working as general practitioners. Participants' mean age was $31 \pm 7.36$ years, and their mean length of work experience was $5 \pm 7.6$ years. We asked the physicians whether they possessed sufficient knowledge concerning hepatitis B infection. One hundred thirty-seven (62.6\%) physicians described themselves as possessing adequate knowledge. One hundred twenty-six physicians stated that the hepatitis B virus passes from the mother to the baby in the intrauterine period, 195 (47.2\%) that transmission occurs during birth, and $92(22.3 \%)$ in the postnatal period. One hundred eighty-seven (85.4\%) stated there was no objection to breastfeeding. One hundred eighty-four (84\%) physicians stated that mothers were screened for hepatitis B infection during pregnancy, and $143(65.3 \%)$ reported having hepatitis B vaccination administered to HBsAg-and AntiHBs-negative pregnant women during pregnancy. One hundred fifty-six (36.4\%) participants reported that they would refer an HBsAg-positive pregnant woman to an infectious diseases or gastroenterology specialist, while $178(40.6 \%)$ and $197(45 \%)$, respectively, stated that the baby of a mother with hepatitis B should receive hepatitis $B$ vaccination and hepatitis B immunoglobulin. One hundred sixty-physicians (38.5\%) stated that 'I would refer a baby identified as HBsAg-positive to a pediatric infection clinic' during the monitoring of a baby born to a mother with hepatitis $B$, while $76(18 \%)$ responded 'I would investigate AntiHBs following hepatitis B vaccination,' and 112 stated 'I would administer a further course of vaccination to babies with AntiHBs $<10 I U / m l$.

Conclusion There are information deficiencies regarding the management of maternal hepatitis B infection management among family physicians working in primary care and providing regular pregnancy and baby monitoring. Family physicians should be given training concerning the monitoring of pregnant women and babies, algorithms to assist the monitoring process must be established, and these must be incorporated into Health Ministry policies.

Key words family physicians, hepatitis B, pregnancy, HBsAg screening, hepatitis B immunoglobulin
} 


\section{GIIRIŞ}

Hepatit B virüs (HBV) enfeksiyonu tüm dünyada giderek azalma eğiliminde olmasına karşın halen halk sağlığı açısından önemli bir hastalıktır. Hepatit B virüsünün önemli geçiş yollarından biri anneden bebeğe bulaştır. Endemik ülkelerde en önemli geçiş yolu olup ülkemizde de yaygın olarak gözlenmektedir. ${ }^{1}$ Dünyada yaklaşık yılda 600,000 kişi HBV enfeksiyonuna bağlı yaşamını yitirmektedir ve bu kişilerin \%21'inin perinatal dönemde enfekte olduğu bilinmektedir. Doğumda gerekli bağışıklama yapılmadığı takdirde hepatit B e-antijen (HBeAg) pozitif anneden doğan çocuklara HBV’ünün geçişi \%70-90 oranında olmakta ve enfeksiyonun \%90'ı kronikleşmektedir. ${ }^{2,3} \mathrm{Bu}$ nedenle hem Hastalık Önleme ve Kontrol Merkezi (CDC) hem de Amerikan Kadın Hastalıkları ve Jinekologlar Koleji her gebelikte hepatit B yüzey-antijeni (HBsAg) taraması yapılmasını önermektedir. ${ }^{4,5}$

Gebelikte HBV prevalansı genel popülasyonla aynıdır. Dünyada annelerin HBsAg pozitiflik oranı \%5, düşük endemik bölgelerde bu oran \%0.6 iken yüksek endemik bölgelerde bu oran \%20'lere çıkmaktadır., ${ }^{6,7}$ Orta endemik bölgede yer alan ülkemizde yapılan çalışmalarda \%1.2 ve \%4.7 gibi farklı oranlar verilmektedir. ${ }^{8-10}$ Ülkemizde yakın zamanda yapılan çok merkezli bir çalışmada 204,865 gebede HBsAg pozitifliği \%1.14 olarak bildirilmiştir. ${ }^{11} \mathrm{Ge}-$ belikte HBV enfeksiyonunun kendi seyri, anne ve fetusa olası zararları, HBV’nün yayılımında kaynak olmaları ve doğum sonrası bebeklerin takibi ve yönetimi açısından önemli bir sorundur. ${ }^{12,13} \mathrm{HBsAg}$ pozitif kadınların gebelikte tespiti hem virüsün yayılımını önlemek hem de anne sağlığını korumak açısından oldukça önemlidir. Gebelik döneminde anne HBV enfeksiyonun immun toleran veya immun aktif fazında olabilir. Gebelikte HBV viral yük yüksekliği (>106 IU/ml) ve HBeAg pozitifliği durumunda anneden bebeğe geçiş riski artmaktadır. ${ }^{14}$

Bu nedenle gebelik döneminde annenin takibe alınması ve gerekirse antiviral tedavi başlanması anne ve bebeği için yakalanmış bir fırsattır. Bu çalışmada gebelik ve bebek takiplerinin yapıldığı birinci basamak aile hekimlerinde maternal kronik hepatit B yönetimi hakkındaki farkındalıklarını belirlemeyi amaçladık.

\section{Gereç ve Yöntem}

Çalışmanın etik kurul onayı (27.02.2020 tarihli, Karar No:22) alındı. Çalışmaya ülkemizde birinci basamak sağlık hizmetlerinde görev yapmakta olan aile hekimleri dahil edildi. Yaklaşık 300 aile hekimine e-posta/elektronik ortam yoluyla ulaşıldı fakat yalnızca 219 aile hekimi anketi cevaplamayı kabul etti. Katılımcilara maternal kronik hepatit B enfeksiyonu yönetimi ile ilgili anket soruları oluşturuldu. Anket soruları rehberler ve literatür bilgileri doğrultusunda hazırlandı. Anket formunda katılımcıların sosyodemografik verilerini içeren (bulundukları şehir, yaş, cinsiyet, çalıştıkları yer, meslekteki yıl ve mesleki durumlar1) bilgiler yer aldı. Maternal hepatit B enfeksiyonu yönetimi hakkında bilgi düzeylerini değerlendirmek amacı ile 8 soru soruldu. Elde edilen cevaplar sayı ve yüzdelik olarak değerlendirildi.

\section{Bulgular}

Çalışmamıza 125 (\%57.1)'i kadın ve 94 (\%42.9)'ü erkek olmak üzere toplam 219 aile hekimi katıldı. Katılımcıların yaş ortalaması $31 \pm 7.36$ yıl, çalışma yılı ortalaması $5 \pm 7.6$ yıl idi. Hekimlerin 43 (\%19.6)'ü aile hekimi uzmanı, 97 (\%44.3)'si aile hekimliği asistanı ve 79 (\%36.1)'i pratisyen hekim olarak çalışmaktaydı. 148 (\%67.6) hekim il merkezinde, 61 (\%27.9)'i ilçede ve 10 (\%4.6)'u köyde çalışmaktayd 1 (Tablo 1). 


\begin{tabular}{|c|c|c|}
\hline \multicolumn{3}{|c|}{ Tablo1. Katılımcıların Sosyodemografik Özellikleri } \\
\hline \multicolumn{3}{|c|}{ Demografik Özellikler } \\
\hline \multirow[t]{2}{*}{ Yaş } & Ort. \pm SD & $31 \pm 7.4$ yıl \\
\hline & & $\mathrm{N}(\%)$ \\
\hline \multirow[t]{2}{*}{ Cinsiyet } & Kadın & $125(\% 57.1)$ \\
\hline & Erkek & $94(\% 42.9)$ \\
\hline \multirow[t]{3}{*}{ Çalışma yılı } & $<5$ yıl & $111(\% 50.7)$ \\
\hline & $6-10$ yll & $55(\% 25.1)$ \\
\hline & $>10$ yll & $53(\% 24.2)$ \\
\hline \multirow[t]{3}{*}{ Mesleki Durum } & Aile hekimi uzmanı & $43(\% 19.6)$ \\
\hline & Aile hekimi asistanı & $97(\% 44.3)$ \\
\hline & Pratisyen hekim & $79(\% 36.1)$ \\
\hline \multirow[t]{3}{*}{ Çalıştığı yer } & İl & $148(\% 67.6)$ \\
\hline & İlçe & $61(\% 27.9)$ \\
\hline & Köy & $10(\% 4.6)$ \\
\hline
\end{tabular}

Hekimlere "hepatit B enfeksiyonu hakkında yeterli bilgiye sahip olup olmadıkları" soruldu. 137 (\%62.6) hekim yeterli bilgiye sahip olduğunu, 82 (\%37.4)'si yeterli bilgiye sahip olmadığını belirtti. Hekimlerin 126 (\%30.5)'sı hepatit B virüsünün anneden bebeğe intrauterin dönemde geçtiğini, 195 (\%47.2)'i doğum esnasında ve 92 (\%22.3)'si postnatal dönemde geçtiğini ifade etti.

Katılımcıların $187(\% 85,4)$ 'si hepatit B'li annenin bebeğini emzirmesinde sakınca olmadığını, 20 (\%9,1)'si hepatit B enfeksiyonu olan annenin bebeğini emzirmesinin kontrendike olduğunu ve $12(\% 5,5)$ 'si konu hakkında bilgisi olmadığını belirtti.

184 (\%84) hekim gebelik döneminde annelere hepatit B enfeksiyonu taraması yapıldığını, 143 (\%65,3) hekim HBsAg ve AntiHBs negatif olan gebeye gebelik döneminde hepatit B aşısı yapılabileceğini belirtti. Katılımcıların 156 $(\% 36,4)$ 'sı HBsAg pozitif tespit edilen gebeyi enfeksiyon hastalıkları veya gastroenteroloji uzmanına yönlendirdiğini belirtti.

"Hepatit B'li anne bebeğine hepatit B aşısı" ve "hepatit B immünglobulin yapılmalıdır" diyen hekimlerin sayısı sırasiyla 178 (\%40.6) ve 197 (\%45) idi. Hepatit B’li anne- den doğan bebeğin takibinde $163(\% 38,5)$ hekim "HBsAg pozitif saptanan bebeği pediatrik enfeksiyon kliniğine yönlendiririm", 76 (\%18) hekim "hepatit B aşı uygulamasından sonra AntiHBs bakarım", 72 (\%17) hekim "hepatit B aşı uygulamasından sonra HBsAg bakarım” ve 112 kişi "AntiHBs $<10 \mathrm{IU} / \mathrm{ml}$ olan bebeklere bir kür aşı daha uygularım” şeklinde cevaplar verdi (Tablo 2).

\begin{tabular}{|c|c|c|}
\hline Anket Soruları & Cevaplar & $\mathrm{N}(\%)$ \\
\hline \multirow{3}{*}{$\begin{array}{l}\text { Hepatit B enfek- } \\
\text { siyonu hakkında } \\
\text { yeterli bilgiye sahip } \\
\text { misiniz? }\end{array}$} & Evet & $137(\% 62.6)$ \\
\hline & Hayır & $82(\% 37.4)$ \\
\hline & Total & $219(\% 100)$ \\
\hline \multirow{4}{*}{$\begin{array}{l}\text { Gebelik döneminde } \\
\text { annelere hepatit B } \\
\text { taraması yapılır mı? }\end{array}$} & Evet & $184(\% 84)$ \\
\hline & Hayır & $25(\% 11.4)$ \\
\hline & Bilmiyorum & $10(\% 4.6)$ \\
\hline & Total & $219(\% 100)$ \\
\hline \multirow{4}{*}{$\begin{array}{l}\text { HBsAg ve AntiHBs } \\
\text { negatif olan gebeye } \\
\text { hepatit B aşısı } \\
\text { yapılır mı? }\end{array}$} & Evet & $143(\% 65.3)$ \\
\hline & Hayır & $54(\% 24.7)$ \\
\hline & Bilmiyorum & $22(\% 10)$ \\
\hline & Total & $219(\% 100)$ \\
\hline \multirow{4}{*}{$\begin{array}{l}\text { Hepatit B virüsü } \\
\text { anneden bebeğe } \\
\text { hangi dönemde/ } \\
\text { dönemlerde geçer?* }\end{array}$} & İntrauterin dönemde & $126(\% 30.5)$ \\
\hline & Doğum sırasında & $195(\% 47.2)$ \\
\hline & Postnatal dönemde & $92(\% 22.3)$ \\
\hline & Total & $413(\% 100)$ \\
\hline \multirow{4}{*}{$\begin{array}{l}\text { Hepatit B enfek- } \\
\text { siyonu tanısı olan } \\
\text { annenin bebeğini } \\
\text { emzirmesi kon- } \\
\text { trendike midir? }\end{array}$} & Evet & $20(\% 9.1)$ \\
\hline & Hayır & $187(\% 85.4)$ \\
\hline & Bilmiyorum & $12(\% 5.5)$ \\
\hline & Total & $219(\% 100)$ \\
\hline
\end{tabular}


J Biotechnol and Strategic Health Res. 2020;4(3):250-256

ALAY, Aile Hekimleri ve Kronik Hepatit B Enfeksiyonu Yönetimi

\begin{tabular}{|c|c|c|}
\hline \multirow{6}{*}{$\begin{array}{l}\text { HBsAg pozitif ve } \\
\text { AntiHBs negatif } \\
\text { olan gebe tespit } \\
\text { ettiğinizde nasıl bir } \\
\text { yol izlersiniz?* }\end{array}$} & $\begin{array}{l}\text { Karaciğer fonksiyon } \\
\text { testlerine (KCFT) bakarım. }\end{array}$ & $89(\% 20.7)$ \\
\hline & $\begin{array}{l}\text { KCFT normalse herhangi } \\
\text { bir şey yapmam. }\end{array}$ & $12(\% 2.8)$ \\
\hline & $\begin{array}{l}\text { KCFT normal olsa bile } \\
\text { enfeksiyon hastalıkları/ } \\
\text { gastroenteroloji uzmanına } \\
\text { yönlendiririm. }\end{array}$ & $122(\% 28.4)$ \\
\hline & $\begin{array}{l}\text { KCFT bozuksa enfeksiyon } \\
\text { hastalıkları/gastroenter- } \\
\text { oloji uzmanına yönlendi- } \\
\text { ririm. }\end{array}$ & $50(\% 11.7)$ \\
\hline & $\begin{array}{l}\text { HBsAg pozitif tespit } \\
\text { ettiğimde enfeksiyon hast- } \\
\text { alıkları/gastroenteroloji } \\
\text { uzmanına yönlendiririm. }\end{array}$ & $156(\% 36.4)$ \\
\hline & Total & $429(\% 100)$ \\
\hline \multirow{4}{*}{$\begin{array}{l}\text { Hepatit B'li anne } \\
\text { bebeğine aşağıda- } \\
\text { kilerden hangisi/ } \\
\text { hangileri yapılır?* }\end{array}$} & Hepatit B aşısı & $178(\% 40.6)$ \\
\hline & Hepatit B immunglobulin & $197(\% 45)$ \\
\hline & $\begin{array}{l}\text { Normal aşılama takvimine } \\
\text { uyarım }\end{array}$ & $63(\% 14.4)$ \\
\hline & Total & $438(\% 100)$ \\
\hline \multirow{5}{*}{$\begin{array}{l}\text { Hepatit B’li anned- } \\
\text { en doğan bebeğin } \\
\text { takibinde hangisi/ } \\
\text { hangileri yapılır?* }\end{array}$} & $\begin{array}{l}\text { Hepatit B aşısının son } \\
\text { dozundan en erken } 1 \text { ay } \\
\text { sonra HBsAg bakarım }\end{array}$ & $72(\% 17)$ \\
\hline & $\begin{array}{l}\text { Hepatit B aşısının son } \\
\text { dozundan en erken } 1 \text { ay } \\
\text { sonra AntiHBs bakarım }\end{array}$ & $76(\% 18)$ \\
\hline & $\begin{array}{l}\text { HBsAg pozitif saptan- } \\
\text { an bebeği pediatrik } \\
\text { enfeksiyon hastalıklarına } \\
\text { yönlendiririm. }\end{array}$ & $163(\% 38.5)$ \\
\hline & $\begin{array}{l}\text { AntiHBs }<10 \mathrm{IU} / \mathrm{ml} \text { olan } \\
\text { bebeklere bir kür (0-1-6. } \\
\text { ay) daha uygularım }\end{array}$ & $112(\% 26.5)$ \\
\hline & Total & $423(\% 100)$ \\
\hline
\end{tabular}

*sorularin birden fazla yanitları mevcut.

\section{Tartışma}

Birinci basamak sağlık birimlerinde çalışan aile hekimleri gebelik takibi ve sonrasında bebeklerin takibinde oldukça önemli rol almaktadırlar. Aile hekimlerinin HBV enfeksiyonu ve gebelikteki önemi hakkında yeterli düzeyde bilgi düzeylerinin olması maternal HBV enfeksiyonu yönetiminde oldukça başarılı sonuçlara neden olacaktır. Çalışmamızda hekimlerin \%62,6’s1 HBV enfeksiyonu hakkında yeterli bilgiye sahip olduklarını belirttiler. \%37.4'lük bir oranda aile hekimi ise yeterli bilgiye sahip olmadıklarını belirttiler. Tıp fakültesi eğitimi ve uzmanlık eğitimleri sırasında HBV enfeksiyonu ve yönetimi hakkında yeterli düzeyde eğitim verilmektedir. Mezuniyet sonrası aile hekimlerinin maternal HBV enfeksiyonu yönetiminin önemi konusunda farkındalıklarını artırmak için eğitimler düzenlenmelidir.

Gerek Hastalık Önleme ve Kontrol Merkezi gerekse Amerikan Kadın Hastalıkları ve Jinekologlar Koleji tarafından HBsAg taramasının her gebelikte tetkik edilmesini önermektedir. ${ }^{4,5}$ Ülkemizde tüm gebe kadınların taranması zorunlu olmamakla birlikte Türkiye Viral Hepatitler Tanı ve Tedavi Klavuzu tüm gebe kadınların taranmasını önermektedir. ${ }^{15}$ Gebelikte HBsAg taranmasının maliyet etkin olduğu gösterilmiştir. ${ }^{16}$ Çalışmamıza katılan aile hekimlerinin büyük bir çoğunluğu gebelikte HBsAg taraması yapıldığını ifade etti. Yapılan tarama ile erken dönemde hastalığa müdahale edilebilir ve bebeklere uygun bağ1şıklama yapılarak HBV'nün geçiş yollarından birine engel olunacaktır.

Hepatit B aşısı ülkemizde seronegatif veya eksik aşılı olan tüm erişkinlere önerilmektedir. 0, 1 ve 6 . ay şeması ile üç doz şeklinde aşı uygulanmaktadır. Gebelik süresince risk varlığı durumunda önerilen aşılar arasında yer almaktadır. ${ }^{17}$ Çalışmaya katılan hekimlerin \%65.3’ü seronegatif gebelerin gebelikte aşılanabileceğini belirtti. Gebelik döneminde hepatit B aşısının yapılmadığını belirten ve aşı yapılıp yapılmaması konusunda bilgisi olmadığını belirten hekimlerin oranı \%34.7 idi. Gebelikte aşı uygulamaları konusunda kurum içi eğitimlerin düzenlenmesi konu hakkındaki bilgi eksikliğini giderecektir.

Hepatit B virüsü başlıca kan ve vücut sıvılarıyla deri ya da mukoza teması ile bulaşmaktadır. HBV'nin anneden bebeğe geçişi intrauterin dönemde, doğum anında yada doğum sonrasında olabilmektedir. ${ }^{2,6}$ Perinatal dönemde al1nan HBV enfeksiyonu önemli oranda kronik enfeksiyona, siroza ve hepatoselüler kanser gibi komplikasyonlara yol 
açabilmektedir. ${ }^{18}$ Anneden bebeğe HBV enfeksiyon geçişini azaltmak için doğumdan sonra ilk 12 saat içinde hepatit $B$ aşısı ve hepatit B immunglobulin (HBIG) yapılmaktadir. ${ }^{10}$ Antenatal tarama programları ve postnatal HBIG ve HBV aşısı uygulaması ile anneden bebeğe geçiş hızı \%510'a kadar inmiştir. ${ }^{6,13,18}$ Çalışmamızda hekimlerin çoğunluğu bebeğe $\mathrm{HBV}$ geçişinin doğum sırasında (\%47.2) ve intrauterin dönemde (\%30.5) olduğunu belirtti. Postnatal dönemde geçiş olduğunu belirten hekim sayısı 92 (\%22.3) idi. HBV enfeksiyonu postanatal dönemde anne ve bebeğin uzun süreli yakın teması sonucu da bulaşabilmekte$\operatorname{dir}^{19}$

Uygun bağışıklamaya rağmen HBV enfeksiyonunun anneden bebeğe geçişi söz konusu olabilmektedir. Hepatit B e-antijen (HBeAg) pozitif gebelerin bebeklerine doğumda yapılan aşı ve HBIG'e rağmen bebeklerin \%10-20'sinin taşıyıcı olduğunu bildiren çalışmalar mevcuttur. ${ }^{20-22}$ Ülkemizde 53 HBV enfeksiyonu olan anne bebeklerinin değerlendirildiği bir çalışmada uygun bağışıklamaya rağmen antikor yanıtı gelişmeyen bebeğin annesinin HBeAg pozitif ve viral yükü yüksek olarak bildirilmiştir. ${ }^{23} \mathrm{Bu}$ nedenle HBV enfeksiyonu olmayan annelerin bebeklerine aşı yanıtına bakılmazken, HBV enfeksiyonu olan anne bebeklerine son aşı dozundan en erken 1 ay sonra HBsAg ve anti-HBs titresi bakılması önerilmektedir. ${ }^{24}$ Anti-HBs düzeyi $10 \mathrm{IU} / \mathrm{ml}$ altında olan bebeklere bir kür aşı (0, 1, 6 . aylarda) daha uygulanmalıdır. Bebeklerin aşı takiplerinin yapıldığı birinci basamak sağlık hizmetlerinde bu konunun bilinmesi gereklidir. Bebeğin sonraki aşılama durumu ve aşı sonrası antikor titresinin değerlendirilmesi bebeğin erken tanısında ve önlem almak için oldukça önemlidir. Çalışmamıza katılan aile hekimlerinin 178 (\%40.6)'i aşı ve 197 (\%45)'si HBIG yapma durumlarını bildiklerini fakat aşı sonrası HBsAg ve AntiHBs bakılma durumunun beklenen düzeyde olmadığını gördük.

Uygun immunoprofilaksiye rağmen $\mathrm{HBsAg}$ pozitif ve AntiHBs negatif tespit edilen bebeklerin mutlaka pediatrik enfeksiyon uzmanına yönlendirilmesi gereklidir.
Katılımcıların 163 (\%38.5)'ü HBsAg pozitif tespit edilen bebeği uygun kliniğe yönlendirilmesi gerektiğini belirtti. $112(\% 26,5)$ hekim de anti-HBs negatif bebeklerde bir kür daha aşı uyguladığını ifade etti.

Çalışmamızda aile hekimlerinin 187 (\%85.4)'si HBV’li annelerin bebeklerini emzirmesinin kontrendike olmadığını belirttiler. Toplam 32 çalışmanın incelendiği bir meta-analiz çalışmasında, aşıları tam olan 5650 bebekte anne sütüne bağlı HBV enfeksiyonu bulaşma hızı \%4.32 olarak bulunmuş ve emzirme ile vertikal bulaşma arasında bir ilişki saptanmamıştır. ${ }^{25} \mathrm{HBsAg}$ pozitif annelerden doğan bebeklere uygulanan hepatit B immünoprofilaksisi sonrası emzirilen ve mamayla beslenen bebekler arasında anti-HBs oluşma hızları açısından fark olmadığ 1 gösterilmiştir., ${ }^{72}$ Amerikan Pediatri Akademisi Kuruluşu ve CDC HBV’li annelerin bebeklerini emzirmesini önermektedir. ${ }^{26,27}$

Gebeliğin kronik HBV enfeksiyonu üzerindeki ya da HBV enfeksiyonun gebelik üzerindeki etkileri net olarak bilinmemektedir. ${ }^{7,18,28,29}$ Kronik HBV enfeksiyonu olan gebedeki yüksek östrojen ve progesteron düzeyleri immünsupresif etki ile HBV replikasyonunu artırabilir. Ayrıca seks steroid düzeylerinin artması karaciğer sentez ve metabolizması üzerinde olumsuz etkilere neden olabilir. ${ }^{30}$ Gebelik döneminde HBV enfeksiyonunda aminotransferazlar normal düzeylerde seyreder ancak akut alevlenmeler görülebilir ve \%20-30 fatalite hızları ile karşılaşılabilir. ${ }^{18,31,32}$ $\mathrm{Bu}$ nedenle gebelik döneminde HBsAg pozitif saptanan gebelerin mutlaka uygun kliniklere yönlendirilerek takiplerinin yapılması gerekmektedir. Gerekli olduğunda kullanılabilecek antiviral tedavi ile hem anne morbidite ve mortalitesi azaltılacak hem de bebeğe bulaş engellenmiş olacaktır. KCFT'lerine bakılmaksızın HBsAg pozitif saptanan gebenin enfeksiyon hastalıkları/gastroenteroloji uzmanına yönlendirilmesi önerilmektedir.15 Çalışmamızda gebelikte HBsAg pozitifliği tespit edildiğinde ve KCFT normal olsa bile hastayı ilgili uzmana yönlendiren hekim sayıları sırasıyla $156(\% 36.4)$ ve 122 (\%28.4) idi. Herhangi bir şey yapmayan hekim sayısı oldukça azdı (12 (\%2.8)). 
Bu da maternal HBV enfeksiyonu yönetiminde hekimlerimizin bilgi düzeylerinin iyi olduğunu göstermektedir.

Anne ve çocuk sağlığı açısından gebelikte HBsAg taraması mutlaka yapılmalıdır. Aşı ile korunabilen bir hastalık olan HBV enfeksiyonun maternal dönemde takibinin yapılması ile perinatal geçişi önlemek mümkündür. HBV’li anne bebeklerinin aşı sonrası antikor yanıtı takibi yapılmalıdır. Çalışmamız gebelik ve bebek takiplerinin yapıldı̆̆ı birinci basamak sağlık kurumlarında görev yapmakta olan aile hekimlerinin maternal kronik HBV enfeksiyonu yönetimi hakkında farkındalıklarına bakış açısı sunmaktadır. Bilgi ve takip eksikliklerinin olması nedeniyle gebe ve bebeklerin takibi konusunda aile hekimlerine eğitimler verilmeli, takip süreçlerine yardımcı olacak algoritmalar oluşturulmalı ve Sağlık Bakanlığı politikaları içerisine dahil edilmelidir.

\section{Çalışmanın Kısıtlılıkları}

Çalışmada maternal KHB enfeksiyon yönetimi konusundaki bilgi düzeyleri aile hekimi uzmanı, asistanı ve pratisyen hekimler olarak ayrı ayrı değerlendirilmedi.

\section{Etik Kurul Onayı}

Çalışmanın B.30.2.ATA.0.01.00/100 sayı numaralı Atatürk Üniversitesi Tıp Fakültesi Klinik Araştırmalar etik kurulu onayı alınmıştır.

\section{Yazar Katkısı}

Concept: HA; Tasarım: HA; Literatür tarama, Materyaller: HA; Veri toplama ve İşleme: HA; Analiz ve yorum: HA; Yazma: HA

\section{Çıkar çatışması}

Yazarın herhangi bir çıkar çatışması yoktur.

\section{Teşekkür}

Çalışmanın istatistiksel analizinde desteği olan Uzm.Dr.

Turgay ARAS’a teşekkür ediyorum. 
J Biotechnol and Strategic Health Res. 2020;4(3):250-256

ALAY, Aile Hekimleri ve Kronik Hepatit B Enfeksiyonu Yönetimi

\section{Kaynaklar}

1. Tosun S. Gebelik ve Hepatit B Viüs Enfeksiyonu. Mediterr J Infect Microb Antimicrob 2016; 5: 4 .

2. Yi P, Chen R, Huang Y, Zhou RR, Fan XG. Management of mother-to-child transmission of hepatitis B virus: Propositions and challenges. J Clin Virol. 2016; 77: 32-9.

3. Tosun S. Viral hepatitlerin ülkemizde değișen epidemiyolojisi. ANKEM Derg. 2013; 27: 128-34.

4. Weinbaum CM, Williams I, Mast EE, Wang SA, Finelli L, Wasley A, Neitzel SM, Ward JW, Centers for Disease C, Prevention. Recommendations for identification and public health management of persons with chronic hepatitis B virus infection. MMWR Recomm Rep. 2008; 57: 1-20.

5. American College of Obstetricians and Gynecologists. ACOG Practice Bulletin No. 86: Viral hepatitis in pregnancy. Obstet Gynecol. 2007; 110: 941- 56.

6. Petrova M, Kamburov V. Breastfeeding and chronic HBV infection: clinical and social implications. World J Gastroenterol. 2010; 16(40): 5042-6.

7. Petersen J. HBV treatment and pregnancy. J Hepatol. 2011; 55(6): 1171-3.

8. Coşkun EI, Dinçgez B, Koyucu RG, Ayanoğlu YT, Ender Yumru A. Gebelerde HBSAg, Anti-HBS ve Anti-HCV siklı̆̆. Perinatal Journal 2011; 19(2): 71-5.

9. Polat S, Camurdan A, Aksakal N, Agladioglu S, Beyazova U, Sahin F, et al. Evaluation of perinatal and intrafamilial hepatitis B prevention programmes in a well child clinic: 9-year follow-up study in Turkey. Transactions of the Royal Society of Tropical Medicine and Hygiene 2011; 105(4): 220-5.

10. Karaca Ç, Karaca N, Taner U, Demir K, Kaymakoğlu S, Beșışılk F, et al. Gebe popülasyonunda hepatit $B, C, D$ virus infeksiyonu sıklğı ve hepatit $C$ virusunun perinatal yolla geçiș oranı. Akademik Gastroenteroloji Dergisi 2003; 2(3): 122-4.

11. Bilman FB, Tosun S, Yildız IE, Alay H et al. Gebelik Döneminde HBsAg Siklğıı ve Risk Faktörlerinin Değerlendirilmesi: Çok Merkezli Çalıșma. Viral Hepatitlerde Eliminasyona Doğru Sempozyum (ENFEKDER), Trabzon, 27-29 Eylül 2019; SS-4; 39-40.

12. Bzowej NH. Optimal management of the hepatitis B patient who desires pregnancy or is pregnant. Curr Hepat Rep. 2012; 11(2): 82-9.

13. Giles ML, Visvanathan K, Lewin SR, Sasadeusz J. Chronic hepatitis B infection and pregnancy. Obstet Gynecol Surv. 2012; 67(1): 37-44.

14. Pan CQ, Duan ZP, Bhamidimarri KR, Zou HB, Liang XF, Li J, Tong MJ: An algorithm for risk assessment and intervention of mother to child transmission of hepatitis B virus. Clinical gastroenterology and hepatology 2012; 10(5): 452-9.

15. Türkiye Viral Hepatitler Tanı ve Tedavi Kilavuzu 2017. https://www.vhsd.org/tr/article/desc/48317/tu-rkiye-viral-hepatitler-tani-ve-tedavi-kilavuzu-2-7.html adresinden 26/02/2020 tarihinde indirilmiştir.

16. Chen HL, Lin LH, Hu FC, Lee JT, Lin WT, Yang YJ, Huang FC, Wu SF, Chen SC, Wen WH, Chu CH, Ni YH, Hsu HY, Tsai PL, Chiang CL, Shyu MK, Lee PI, Chang FY, Chang MH. Effects of maternal screening and universal immunization to prevent mother-to-infant transmission of HBV. Gastroenterology. 2012; 142: 773-81.

17. Recommended Adult Immunization Schedulefor ages 19 years or older. United States 2020. Centers for Disease Control and Prevention. Erişim adresi: https://www.cdc.gov/vaccines/ schedules/hcp/imz/adult.html adresinden 26/02/2020 tarihinde indirilmiștir.
18. Degli Esposti S, Shah D. Hepatitis B in pregnancy: challenges and treatment. Gastroenterol Clin North Am. 2011; 40(2): 355-72.

19. Demir NA, Asan A, Çelen MK, Köse Ş, et al. Gebelikte Kronik Hepatit B Yönetimi: Türk Klinik Mikrobiyoloji ve İnfeksiyon Hastalıları Derneği Viral Hepatit Çalışma Grubu Uzlașı Raporu. Klimik Dergisi 2013; 26(Özel Sayı 1): 12-9.

20. Zhang L, Gui X, Wang B, Ji H, Yisilafu R, Li F, Zhou Y, Zhang L, Zhang H, Liu X. A study of immunoprophylaxis failure and risk factors of hepatitis $B$ virus mother-to-infant transmission. Eur J Pediatr. 2014; 173: 1161-8.

21. Tran TT. Hepatitis B and pregnancy. Clin Infect Dis. 2016; 62(Suppl 4): 314-7.

22. Lin X, Guo Y, Zhou A, Zhang Y, Cao J, Yang M, Xiao F, Zhang B, Du Y. Immunoprophylaxis failure against vertical transmission of hepatitis $B$ virus in the Chinese population: a hospital-based study and a meta-analysis. Pediatr Infect Dis J. 2014; 33: 897-903.

23. Alay H, Șahiner M, Kadioğlu BG, Alay RA. Outcomes of Passive-Active Immunoprophylaxis Administered to Infants of Mothers Infected with Hepatitis B Virus in Erzurum, Turkey. JCP 2019; 17(1): 110-120.

24. Schillie S, Murphy TV, Fenlon N, Ko S, Ward JW. Update: shortened interval for postvaccination serologic testing of infants born to hepatitis B-infected mothers. MMWR 2015; 64(39): 1118-20.

25. Zheng $Y, L u Y, Y e Q$, et al. Should chronic hepatitis B mothers breastfeed? A meta analysis. BMC Public Health. 2011; 11: 502.

26. Mast EE, Margolis HS, Fiore AE, Brink EW, Goldstein ST, Wang SA, Moyer LA, Bell BP Alter MJ; Advisory Committee on Immunizati $\urcorner$ on Practices (ACIP). A comprehensive immunization strategy to eliminate transmission of hepatitis $B$ virus infection in the United States: recommendations of the Advisory Committee on Immu-nization Practices (ACIP) part 1: immunization of infants, children, and adolescents. MMWR Recomm Rep. 2005; 54(RR-16): 1-31.

27. Gartner LM, Morton J, Lawrence RA, et al. American Academy of Pediatrics Section on Breastfeeding. Breastfeeding and the use of human milk. Pediatrics. 2005; 115(2): 496-506.

28. Borgia G, Carleo MA, Gaeta GB, Gentile I. Hepatitis B in preg ᄀnancy. World J Gastroenterol. 2012; 18(34): 4677-83.

29. Han GR, Xu CL, Zhao W, Yang YF. Management of chronic hepatiาtis B in pregnancy. World J Gastroenterol. 2012; 18(33): 4517-21.

30. Nguyen G, Garcia RT, Nguyen N, Trinh H, Keeffe EB, Nguyen MH. Clinical course of hepatitis B virus infection during pregnancy. Aliment Pharmacol Ther. 2009; 29(7): 755-64.

31. Rapti IN, Hadziyannis SJ. Treatment of special populations with chronic hepatitis B infection. Expert Rev Gastroenterol Hepatol. 2011; 5(3): 323-39.

32. Kakogawa J, Sakurabashi A, Sadatsuki M, Gomibuchi H, Minoura S. Chronic hepatitis B infection in pregnancy illustrated by a case of successful treatment with entecavir. Arch Gynecol Obstet. 2011; 284(6):1595-6. 